Southern Illinois University Carbondale

OpenSIUC

Publications

Fisheries and Illinois Aquaculture Center

$11-2004$

\title{
Comparison of Bluegill Consumption Rates by Largemouth Bass and Sunshine Bass in Structured and Nonstructured Artificial Environments
}

Christopher W. Hickey

Christopher C. Kohler

Southern Illinois University Carbondale

Follow this and additional works at: http:// opensiuc.lib.siu.edu/fiaq pubs

(c) by the American Fisheries Society 2004

Published in Transactions of the American Fisheries Society, Vol. 133, Issue 6 (November 2004) at doi:

10.1577/T03-190.1

Notes.

\section{Recommended Citation}

Hickey, Christopher W. and Kohler, Christopher C. "Comparison of Bluegill Consumption Rates by Largemouth Bass and Sunshine Bass in Structured and Nonstructured Artificial Environments." (Nov 2004).

This Article is brought to you for free and open access by the Fisheries and Illinois Aquaculture Center at OpenSIUC. It has been accepted for inclusion in Publications by an authorized administrator of OpenSIUC. For more information, please contact opensiuc@lib.siu.edu. 


\title{
Comparison of Bluegill Consumption Rates by Largemouth Bass and Sunshine Bass in Structured and Nonstructured Artificial Environments
}

\author{
Christopher W. Hickey And Christopher C. KohleR* \\ Fisheries and Illinois Aquaculture Center and Department of Zoology, \\ Southern Illinois University, Carbondale, Illinois 62901-6511, USA
}

\begin{abstract}
We compared consumption rates of bluegills Lepomis macrochirus by largemouth bass Micropterus salmoides and sunshine bass (female white bass Morone chrysops $\times$ male striped bass $M$. saxatilis) in structured (about $50 \%$ coverage with artificial vegetation) and nonstructured 2,000-L fiberglass tanks. In the presence of structure, instantaneous bluegill mortality from consumption by largemouth bass was significantly higher than that caused by sunshine bass but was similar when structure was absent. Instantaneous bluegill mortality from consumption by wild largemouth bass was significantly higher than by pellet-trained largemouth bass in both structured and nonstructured environments. When pellet-trained sunshine bass served as the predator, bluegill instantaneous mortality rate was similar within structured and nonstructured environments. Our findings indicate that sunshine bass are not as adept as largemouth bass at consuming bluegills in the presence of structure but that, unlike largemouth bass, their consumption rates on bluegills are not affected by prior predatory experience.
\end{abstract}

Small freshwater impoundments in North America are often stocked with a combination of largemouth bass Micropterus salmoides, sunfish Lepomis spp., and channel catfish Ictalurus punctatus (Flickinger et al. 1999). Bluegills L. macrochirus thrive in these waters because the normally abundant stands of macrophytes provide excellent habitat for invertebrate prey (Savino et al. 1992) and also provide bluegills with some protection against predation (Savino and Stein 1982; Gotceitas 1990). Largemouth bass can move effectively through vegetated areas, and their ability to use an ambush foraging strategy makes them an efficient predator in such environments (Savino and Stein 1989). However, as plant density increases, the ability of piscivores to capture prey such as bluegills generally decreases (Savino and Stein 1982; Gotceitas and Colgan 1989).

Other species of sport fish have been suggested to supplement the largemouth bass-bluegill combination. Of particular interest are hybrid striped

\footnotetext{
* Corresponding author: ckohler@siu.edu
}

Received October 28, 2003; accepted May 26, 2004 bass (i.e., cross of white bass Morone chrysops and striped bass $M$. saxatilis). Hybrid striped bass are pelagic piscivores that forage on small prey living in open waters. They prefer to feed on soft-rayed fishes (e.g., clupeids) even when they are not the most abundant prey item (Crandall 1979), but will occasionally feed on small spiny-rayed fishes (Gilliland and Clady 1984; Neal et al. 1999). However, when stocked in small impoundments containing only centrarchid prey, the typical search and capture method employed by hybrid striped bass in open waters may not be sufficient, particularly in vegetated areas. Accordingly, we compared consumption of bluegills by largemouth bass and sunshine bass (female white bass $\times$ male striped bass) in structured and nonstructured environments. Because foraging success may be influenced by previous experience, we also compared predation on bluegills by wild and pellet-trained largemouth bass and hybrid striped bass.

\section{Methods}

Experimental conditions and test fish.-We conducted four trials using three replicates of six 2000-L fiberglass tanks (18 total) in each trial. The tanks (183 cm diameter) were each filled with $1,185 \mathrm{~L}$ of water to a depth of about $0.8 \mathrm{~m}$ and maintained at $25-27^{\circ} \mathrm{C}$ and to equivalent water quality conditions by separate biofiltration units. Tanks were individually covered with black plastic tarps and artificially lit for $12 \mathrm{~h} / \mathrm{d}$ with a $60-\mathrm{W}$ light bulb controlled by a timer. Nine tanks were randomly fitted to about $50 \%$ coverage with structure consisting of $1.0 \mathrm{~m}^{2}$ of artificial vegetation comprised of buoyant 0.9 -m polypropylene string uniformly attached to rigid $6.5-\mathrm{mm}$ polyethylene netting fastened with silicon-based caulk to tank bottoms. The artificial vegetation loosely floated to the surface and split the tanks into nearly equivalent halves, one with cover and the other with open water. We provided each of the structured tanks with an artificial stem density of 500 stems/ $\mathrm{m}^{2}$; nearly double the threshold level of plant density $\left(276 \mathrm{stems} / \mathrm{m}^{2}\right)$ experimentally found to re- 
duce foraging success of predators on bluegills (Gotceitas and Colgan 1989). We stocked each tank for each trial with 25 juvenile bluegills (total length $=50 \pm 5 \mathrm{~mm}$ [mean $\pm \mathrm{SD}]$ ), all of which had previous experience with predators.

In each of the four trials we randomly assigned each tank in each six-tank replicate one of six experimental treatments (i.e., predator type and structure) and repeated this for each of the three replicates. In the first two trials, we used two wild predators (total length $=23 \pm 2 \mathrm{~cm}$ ) per treatment: sunshine bass with and without structure, largemouth bass with and without structure, or no predators with and without structure (control). In the third trial, the six treatments were largemouth bass with and without structure, pellet-trained largemouth bass with and without structure, and no predators with and without structure (control). The fourth trial was identical to the third except wild and pellet-trained sunshine bass replaced largemouth bas as the predators. All wild predators were presumably experienced in capturing live fish. No individual predators or bluegill were used in more than one trial.

We harvested the bluegills from earthen ponds and stocked them into the experimental tanks 24 $\mathrm{h}$ before adding the predators; this allowed bluegills to acclimate to temperature, water quality, and when present, artificial vegetation. Before stocking experimental tanks, we housed both predators separately in identical holding tanks with no structure for approximately 4 weeks and, to ensure a common baseline hunger, fed them daily with stunned or recently killed bluegills until apparent satiation. For each trial, we stocked each tank with the two randomly assigned predators and proceeded to successive tanks at 10-min intervals to allow sufficient time to conduct accurate prey counts for individual tanks at the selected times $(24,48,72$, 96, and $120 \mathrm{~h}$ poststocking).

Analysis of daily prey counts.-Each trial was a completely randomized block design. We analyzed data by the general linear model (analysis of variance [ANOVA]) in the Statistical Analysis System (SAS Institute, Inc. 2002). Because no significant differences occurred between the first two trials, we analyzed their prey count data as one completely randomized trial. The third and fourth trials were analyzed separately. Bluegill mortality in the control tanks in all four trials was minimal $(1 \%)$, so we assumed all mortality in other treatments was caused by predation.

An analysis was performed on the daily prey counts to generate bluegill instantaneous mortality rates. We performed a simple linear regression on each treatment with $\log _{e}$ (number of bluegills remaining +1$)$ as the dependent variable and time (h) as the independent variable. Bluegill instantaneous mortality $(Z)$ was derived from the regression under the premise that slope $=-Z$ (Van Den Avyle and Hayward 1999). In the absence of fishing mortality, all mortality is considered natural. A higher value of $Z$ indicates a greater mortality rate, which in turn is directly related to the foraging success of the predator. The resulting slopes of the regression lines were tested for heterogeneity using the general linear model (ANOVA). Significance for all comparisons was set at $\alpha=0.05$.

\section{Results}

Wild Largemouth Bass versus Wild Sunshine Bass

Largemouth bass were more adept at consuming bluegills than sunshine bass in the presence of structure (Figure 1a); bluegill instantaneous mortality rate was significantly higher $(F=76.63$; df $=1,10 ; P<0.0001)$ for largemouth bass $(Z=$ $0.022)$ than for sunshine bass $(Z=0.005)$ predation. Conversely, consumption on bluegills by largemouth bass $(Z=0.030)$ and sunshine bass $(Z$ $=0.029$ ) was similar in nonstructured tanks (Figure 1a).

\section{Wild versus Pellet-Trained Predators}

Largemouth bass. - Wild largemouth bass $(Z=$ 0.030 ) consumed bluegills more rapidly than pellet-trained largemouth bass $(Z=0.004)$ in structured tanks (Figure 1b), resulting in significantly higher $(F=103.49$; df $=1,4 ; P<0.0001)$ bluegill instantaneous mortality rates $(Z=0.030$ and 0.004 , respectively). Likewise, in nonstructured tanks, the bluegill instantaneous mortality rate caused by predator consumption (Figure $1 \mathrm{~b}$ ) was significantly greater $(F=64.97 ; \mathrm{df}=1,4 ; P<$ $0.0001)$ for wild $(Z=0.029)$ than for pellet-trained largemouth bass $(Z=0.004)$.

Sunshine bass.-Wild and pellet-trained sunshine bass in structured and nonstructured tanks consumed bluegills at similar rates in their respective treatments (Figure 1c). Bluegill instantaneous mortality rates in structured tanks did not differ significantly $(F=0.26 ; \mathrm{df}=1,4 ; P=0.611)$ between wild $(Z=0.005)$ and pellet-trained $(Z=$ $0.004)$ sunshine bass; similarly, in nonstructured tanks the bluegill instantaneous mortality rate in the presence of wild $(Z=0.031)$ and pellet-trained $(Z=0.032)$ sunshine bass did not differ significantly $(F=0.02$; df $=1,4 ; P=0.893)$. 

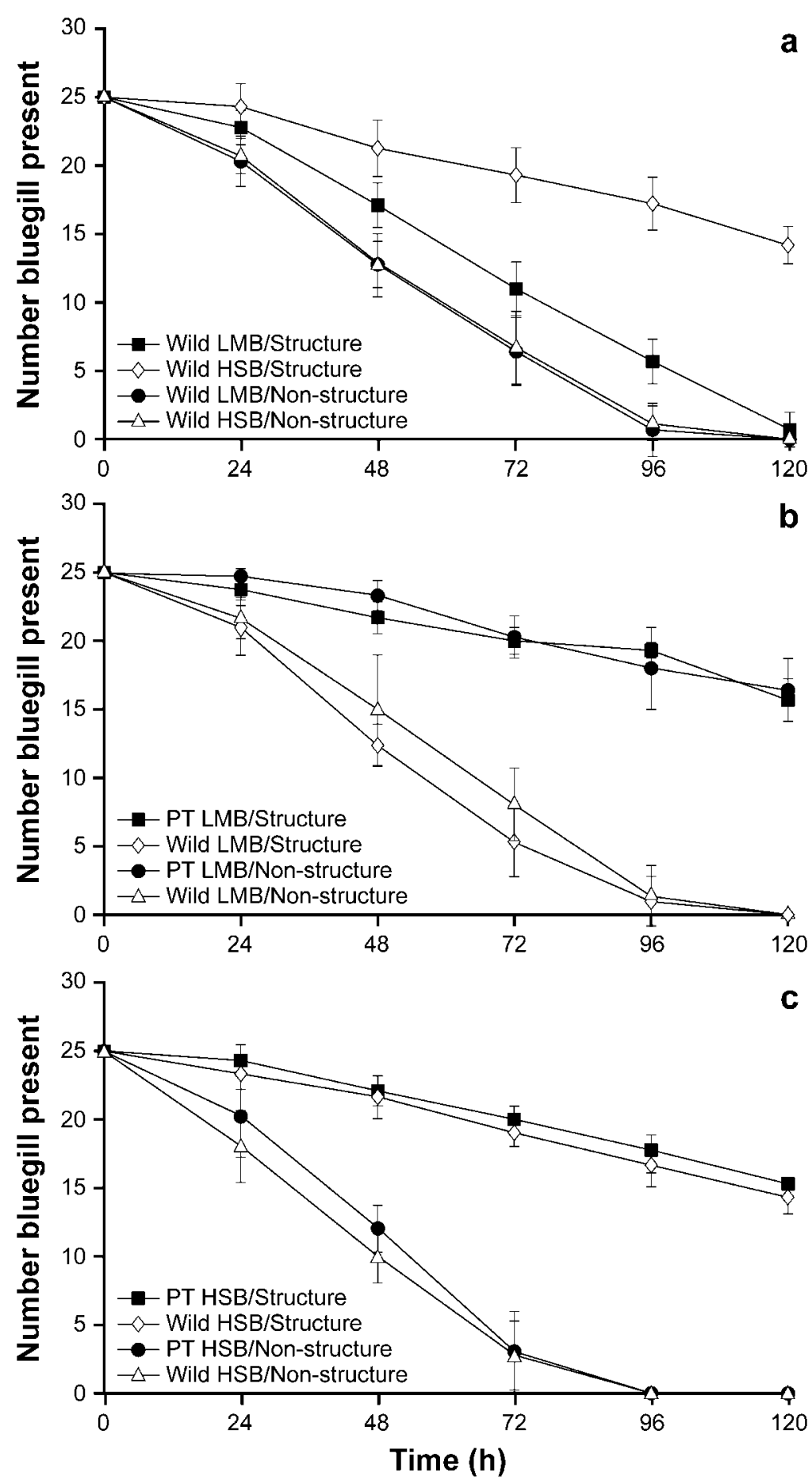

FIGURE 1.-Mean number ( $\pm 1 \mathrm{SE}$ ) of bluegills remaining at preset times over a 120 -h period in structured and nonstructured tanks containing (a) wild largemouth bass (LMB) and wild sunshine bass (HSB), (b) wild largemouth bass and pellet-trained (PT) largemouth bass, and (c) wild sunshine bass and pellet-trained sunshine bass. 


\section{Discussion}

We found the largemouth bass consumption rate on bluegills under experimental conditions to be significantly greater than that by sunshine bass in the presence of structure. When largemouth bass exist in natural environments, they exhibit a preference to vegetated littoral areas (Messing and Wicker 1986), to which they are well adapted, considering their ambush foraging strategy and ease at maneuvering within the vegetation (Savino and Stein 1989). The sunshine bass, however, is a schooling, open-water predator, and as such, has successfully been used in larger reservoirs with an abundant supply of pelagic forage fish (e.g., gizzard shad Dorosoma cepedianum and threadfin shad $D$. petenense; Jahn et al. 1987). Under natural conditions, these predators may select areas close to aquatic vegetation (Jones and Rogers 1998), but there is no evidence that they actually use structure during foraging. In our study, the nonstructured tanks served as a surrogate for pelagic conditions, which presumably allowed the sunshine bass to exhibit foraging behaviors comparable to living in a natural, open-water environment. The significant decrease in consumption rate on bluegills by sunshine bass in structured tanks could be partly due to their shift in behavior. We observed that these predators remained essentially motionless in the vegetation, whereas those in nonstructured tanks freely roamed about. Bluegill behavior in the presence of predators was generally consistent with descriptions by Moody et al. (1983), which included a tendency to take immediate refuge at the surface-tank-wall interface in the absence of structure or when chased out of the structure by a predator.

Stocking predators reared on commercial feed is common in fisheries management. Studies looking at other species of pellet-trained predators, such as muskellunge Esox masquinongy $\times$ northern pike E. lucius, concluded their lack of foraging success was attributable to their inability to effectively capture and handle spiny-rayed fishes, such as bluegills (Gillen et al. 1981; Tomcko et al. 1984). We did not observe this to be the case under experimental conditions with either pellet-trained largemouth bass or sunshine bass. However, pellettrained largemouth bass initially displayed little interest in pursuing bluegills, possibly due to a lack of a search image for bluegills. The search image tends to develop as a result of previous experience, and over time the predator is expected to switch to the most common prey item (Murdoch
1969; Murdoch and Oaten 1975). We noted an initial lack of interest in bluegills by pellet-trained largemouth bass, regardless of the presence of structure.

Previous studies examining the use of hybrid striped bass as a possible sport fish in small lakes and ponds indicate they do not perform as well as those stocked into larger reservoirs, particularly when the small water body is vegetated (Farquhar 1982; Neal et al. 1999). The vast array of vegetation types and characteristics further complicates predator-prey interactions. Foraging success and behavior of predators is influenced by such characteristics as stem density (Anderson 1984; Savino and Stein 1989; Hayse and Wissing 1996), percent coverage (Miranda and Pugh 1997), and architecture of the vegetation communities (Dibble and Harrel 1997; Valley and Bremigan 2002). Further study is needed to compare hybrid striped bass (both crosses) and largemouth bass foraging success in natural environments, particularly in small impoundments containing significant stands of macrophytes.

\section{Acknowledgments}

This study was conducted by the first author as a thesis to partially meet the requirements for a Master of Science degree in the Department of Zoology, Southern Illinois University Carbondale (SIUC). We thank Roy Heidinger and Matthew Whiles for their guidance during the preparation of the study. Ryan Oster, Paris Collingsworth, and Ryan Lane provided valuable assistance in execution and analysis of the study. The SIUC Fisheries and Illinois Aquaculture Center provided the funds and facilities necessary to carry out this research. The manuscript was much improved by the comments of Jim Garvey and two anonymous reviewers.

\section{References}

Anderson, O. 1984. Optimal foraging by largemouth bass in structured environments. Ecology 65:851861.

Crandall, P. S. 1979. Evaluation of striped bass $\times$ white bass hybrids in a heated Texas reservoir. Proceedings of the Annual Conference Southeastern Association of Fish and Wildlife Agencies 32(1978): 588-598.

Dibble, E. D., and S. L. Harrel. 1997. Largemouth bass diets in two aquatic plant communities. Journal of Aquatic Plant Management 35:74-78.

Farquhar, B. W. 1982. Evaluation of striped bass $\times$ white bass hybrids in small impoundments. Annual Proceedings of the Texas Chapter, American Fisheries Society 4:55-66. 
Flickinger, S. A., F. J. Bulow, and D. W. Willis. 1999. Small impoundments. Pages 561-587 in C. C. Kohler and W. A. Hubert, editors. Inland fisheries management in North America, 2nd edition. American Fisheries Society, Bethesda, Maryland.

Gillen, A. L., R. A. Stein, and R. F. Carline. 1981. Predation by pellet-reared tiger muskellunge on minnows and bluegills in experimental systems. Transactions of the American Fisheries Society 110:197209.

Gilliland, E. R., and M. D. Clady. 1984. Diet overlap of striped bass $\times$ white bass hybrids and largemouth bass in Sooner Lake, Oklahoma. Proceedings of the Annual Conference Southeastern Association of Fish and Wildlife Agencies 35(1981):317-330.

Gotceitas, V. 1990. Foraging and predator avoidance: a test of a patch choice model with juvenile bluegill sunfish. Oecologia 83:346-351.

Gotceitas, V., and P. Colgan. 1989. Predator foraging success and habitat complexity: quantitative test of the threshold hypothesis. Oecologia 80:158-166.

Hayse, J. W., and T. E. Wissing. 1996. Effects of stem density of artificial vegetation on abundance and growth of age-0 bluegills and predation by largemouth bass. Transactions of the American Fisheries Society 125:422-433.

Jahn, L. A., D. R. Douglas, M. J. Terhaar, and G. W. Kruse. 1987. Effects of stocking hybrid striped bass in Spring Lake, Illinois. North American Journal of Fisheries Management 7:522-530.

Jones, M. S., and K. B. Rogers. 1998. Palmetto bass movements and habitat use in a fluctuating Colorado irrigation reservoir. North American Journal of Fisheries Management 18:640-648.

Messing, C. L., and A. M. Wicker. 1986. Home range, spawning migrations, and homing of radio-tagged Florida largemouth bass in two central Florida lakes. Transactions of the American Fisheries Society 115:286-295.

Miranda, L. E., and L. L. Pugh. 1997. Relationship between vegetation coverage and abundance, size, and diet of juvenile largemouth bass during winter. North American Journal of Fisheries Management 17:601-610.

Moody, R. C., J. H. Helland, and R. A. Stein. 1983. Escape tactics used by bluegill and fathead minnows to avoid predation by tiger muskellunge. Environmental Biology of Fishes 8:61-65.

Murdoch, W. W. 1969. Switching in general predators: experiments on predator specificity and stability of prey populations. Ecological Monographs 39:335354.

Murdoch, W. W., and A. Oaten. 1975. Predation and population stability. Advances in Ecological Research 9:2-131.

Neal, J. W., R. L. Noble, and J. A. Rice. 1999. Fish community response to hybrid striped bass introduction into small warmwater impoundments. North American Journal of Fisheries Management 19: 1044-1053.

SAS Institute, Inc. 2002. SAS/STAT guide for personal computers, version 8.1. SAS Institute, Inc., Cary, North Carolina.

Savino, J. F., E. A. Marschall, and R. A. Stein. 1992. Bluegill growth as modified by plant density: an exploration of underlying mechanisms. Oecologia 89:153-160.

Savino, J. F., and R. A. Stein. 1982. Predator-prey interaction between largemouth bass and bluegills as influenced by simulated submersed vegetation. Transactions of the American Fisheries Society 111: 255-266.

Savino, J. F., and R. A. Stein. 1989. Behavioral interactions between fish predators and their prey: effects of plant density. Animal Behavior 37:311321.

Tomcko, C. M., R. A. Stein, and R. F. Carline. 1984. Predation by tiger muskellunge on bluegill: effects of predator experience, vegetation, and prey density. Transactions of the American Fisheries Society 113:588-594.

Valley, R. D., and M. T. Bremigan. 2002. Effects of macrophyte bed architecture on largemouth bass foraging: implications of exotic macrophyte invasions. Transactions of the American Fisheries Society 131:234-244.

Van Den Avyle, M. J., and R. S. Hayward. 1999. Dynamics of exploited fish populations. Pages 127166 in C. C. Kohler and W. A. Hubert, editors. Inland fisheries management in North America, 2nd edition. American Fisheries Society, Bethesda, Maryland. 